\title{
Influences of COVID-19 on the Primary and Secondary Education in China
}

\author{
Xue Bai \\ Xi'an Technological University, Xi'an, Shaanxi, 710000, China \\ *Corresponding author. Email: gaoming@cas-harbour.org
}

\begin{abstract}
The sudden outbreak of COVID-19 disrupted China's primary and secondary school regular education teaching plan. In response to COVID - 19, Ministry of Education of the People's Republic of China has issued the document of "classes suspended, but learning continues" [1]. Even though online education effectively countering the COVID - 19 impacts on the education system, there are still problems about online education in China that need to be solved. This article will discuss Influences of COVID-19 for Primary and Secondary Online Education in China, such as the malfunction of Internet platform infrastructure, the deficiency of teacher's information literacy, the monotony of teaching content, lack of home-school cooperation, and low learning efficiency. To solve these problems, suggestions are also put forward. Firstly, schools and teachers need to increase the research on online education. For example, schools should set up professional teams to participate in the development of online education and actively construct online education evaluation standards for teachers. Teachers should study the method for online education, which can not only improve students' interest in learning, but also make full use of the advantages of the network to broaden students' knowledge. In addition, communication and cooperation between parents and schools should be strengthened. Parents should strive to create a good and healthy learning environment for students, assist teachers to achieve the supervision, and actively give feedback about the problems of students' learning at home. Students should also adjust their mentality, try to adapt to the environment of online education as soon as possible, strengthen their self-supervision ability, and improve their learning efficiency.
\end{abstract}

Keywords: Online education, Informationization, Problems, Suggestion, Epidemic

\section{INTRODUCTION}

During the Spring Festival in 2020, there is an outbreak of COVID-19 in Wuhan, China. In order to prevent the spread of the COVID-19, communities were closed down, people are suggested to keep social distance and avoid gathering. Furthermore, school classes had to be suspended. Although these measures effectively stopped the spread of COVID-19, suspended classes disrupted primary and secondary schools' regular education teaching plan in China. In response to COVID-19, Ministry of Education of the People 's Republic of China has issued the document of "classes suspended, but learning continues" [1], and effectively deployed the strategy of "use screen illuminates the future, use technology to overcome barriers" [2]. This essay will discuss the problems of online education in China, namely, the problems about Internet platform infrastructure, the teaching support from schools and teachers, the cooperation between school and family and students online studying difficulties. Besides, some suggestions for primary and secondary online education in China will be put forward.

\section{PROBLEMS BROUGHT BY COVID-19 TO ONLINE EDUCATION IN CHINA}

\subsection{Problems about Network equipment}

First of all, the outbreak of COVID-19 has broken the rule of teaching only takes place at the classroom, and Internet has become a major part of teaching. However, the mass of Internet platform infrastructure is not capable of guaranteeing the whole country's large-scale online education. In the sudden demands and use process, there are a large number of problems, such as Internet collapse, image lag, noise interference, and technology support are insufficient, which affect the quality of teaching. Especially in remote areas, these 
problems are acute. For example, "some students in northwest China have to climb to the roof or sit in the wide field to solve the problem of poor network." [3]

\subsection{Problems about online teaching technology, methods and content}

In addition to equipment, online education also puts forward high requirements for teachers' information literacy and ability. In particular, many primary and secondary school teachers in the northwest of China are not proficient in using Internet teaching technology. It is hard for them to make teaching courseware, record teaching micro-videos, and prepare teaching documents, especially, they have insufficient ability to cope with unexpected problems such as technical failures during online teaching. Moreover, it's the first time for scores of teachers to contact with the mode of online education. Most of the time the class became presentation. Even if the teacher is full of teaching passion, the teaching effects will be significantly reduced due to the lack of interaction between teachers and students, and the interaction between students and students. For example, many workshops, discussion, and the process of question-and-answer will be cut down. As to the core of teaching content, Chinese Studies, mathematics, and English studies are still dominant in online education. Although there are some teachers combine patriotism education, life education, and mental health education with online classes. However, it is undeniable the teaching content is monotonous and restricted by the online environment, it is difficult to carry out some classes like PE class, laboratory class and so on.

\subsection{Problems about the cooperation between parents and school}

The separation of teachers and students in time and space brings challenges to the remote monitoring and teaching effect of online education. Because there is no face to face teaching, if students self-discipline ability is poor, the teacher can't restrain students in time from playing games, listening to music, watching videos or reading novels and so on during sessions. In order to ensure the regular development of teaching, schools have to put forward requirements for parents, who replace teachers to monitor students' learning. However, parents' understanding of monitor necessity is still insufficient. The research group of China National Institute of Education Sciences conducted a questionnaire survey among nearly 180,000 teachers and more than 1.8 million parents in primary and secondary schools across the country, "with only $46.79 \%$ of parents saying 'yes, it is necessary' accounting for less than half. $30.65 \%$ of parents said 'sometimes, it is not necessary' and $18.56 \%$ of parents said 'necessary, but they have no time." [4] It can be seen from the data that home and school education cooperation in online education has not yet formed consensus view. Otherwise, according to the data of teaching effect of online education, "only $12.85 \%$ of parents said that their student are very attentive in online learning, listening carefully and taking notes seriously." [4]

\subsection{Problems about home environment}

Although study at home are novel for student at the beginning, we have to admit that some of the family environment is not suitable for learning. For example, there are a variety of complex noises from home, the noises of the younger brother or sister, the decoration sounds from the neighborhoods, the loud voice from living room's TV. These noises will not only lead to non-ideal learning environment, but also seriously affect the online learning effect. There are also many psychological problems for student, such as the absence of their daily learning routine and the lack of accompany from classmates, which may lead to poor learning efficient and enjoyment. Staying at home also inevitably leads to conflict with family members, anxiety.

"Epidemic is not only a test of the ability of China's education system to cope with major public health emergencies, but also an opportunity for the realization of educational informatization in the future." [5]

Because online education is not limited by time and place, students can obtain high-quality teaching resources from all over the world, and the online classes can be watched repeatedly and so on. We should realize that online education is not only the one of the trends of future education development, but also the inevitable result of education information. Analyzing the current situation of online education rationally under the epidemic situation and solving problems effectively on the level of school, teacher, parent and student have great practical significance for promoting China's education informatization and realizing the goal of education modernization.

\section{SUGGESTIONS}

\subsection{Suggestions to school}

If school wants to achieve high standards of instruction in online education, schools should vigorously strengthen research on online education, guide educational researchers to deeply participate in online education, support teaching researchers and teachers to form teams, and carry out high-level teaching by creating colorful learning themes and task situations. In terms of technical support, schools should set up a special online learning service center with specialized technical personnel to provide perfect technical support and timely solve technical failures in 
the process of online education for teachers and students.

In the past, on teachers' level, there were standards for primary and secondary school teachers, including teaching standards, educating standards, organizing teaching standards and evaluating teaching standards. But now it is time to add a standard for online education for teachers. It should include the ability to search and organize Internet information, the ability to use computers, the ability to make online teaching documents and the ability to use informationized teaching tools. Students' autonomy is very important in the teaching process. Students who can mobilize, control and arrange themselves often have better results in learning. Therefore, the most important standard for online teachers is whether they can mobilize students' learning enthusiasm through class design and teaching organization, break the "scripted" teaching method, and let students explore new knowledge, improve their critical thinking and transfer applications under the task-driven.

\subsection{Suggestions to teachers}

Teachers should concentrate on researching online teaching methods which are different from traditional classroom. Teachers should put more energy in the production of teaching documents for online teaching. Making full use of the characteristics of online teaching can increase the interest and interactivity. Games, cartoon and so on are excellent tools to improve students' interest in learning. Teaching plan should be focus on how to select and teach with the appropriate Internet tools, but do not distract students' attention. In the process of teaching, the interaction between teachers and students should be strengthened as much as possible, and the participation and concentration of students should be continuously enhanced through online Question and Answer, discussion and other forms, so as to guide students to complete the study efficiently. At the same time, teacher should make full use of the advantages of the network to broaden students' knowledge. In traditional teaching, the content and time of class are limited, thus the scope of knowledge is also limited. Teachers should figure out how to use the curriculum resources and network platform support to design the best class with not only the intellectual education, but also education of moral, physical, aesthetic, and labor.

\subsection{Suggestions to parents}

Compared with traditional teaching models, online education lacks the real classroom atmosphere, students are easy to be affected by various factors, resulting in weariness, anxiety and a series of problems. In this special period, parents should understand their student's difficulties in learning at home and give their student positive support. On the one hand, parents should timely give their student psychological counseling, so that student can maintain the best emotional input into learning, on the other hand, parents should create a good learning environment at home. For example, when student is learning online, parents should consciously speak quietly.Teachers and parents should strengthen communication and cooperation. Parents should give real feedback to teachers on their student's study at home in time, which is helpful for teachers to put forward reasonable suggestions. After online courses, it does not mean that learning is over, nor the student really master and absorb knowledge. Parents should urge their student to complete the tasks assigned by the teacher on time, correct their homework in time, make up for the missing question and consolidate the learning effect. Parents can also try to use the right method to guide student to self-learning, self-management, at the end, student will have more harvest.

\subsection{Suggestions to students}

Student should learn to arrange their own hours reasonably, according to the daily online course time to set the daily learning time, homework time, rest time, entertainment time and so on. Student should be aware that the change of learning style cannot reduce the requirements of learning habits, otherwise the learning ability is difficult to improve, and the class effect will be greatly reduced. Online class is dominated by teacher's teaching, thus the pace of online learning is faster than face-to-face class. Student should preview the next day's online class in advance, so that they can adapt to online learning more quickly and guarantee the good learning effects. Many of the current platforms also record lessons while they are live, thus lessons can be relearned by students. If students are unable to participate in the live class or disturbed by the surrounding environment, they must study independently by replaying the lecture video.Online education can break the limitation of time and space, deliver knowledge to students at anytime and anywhere. If students who live in remote western rural areas of China, they can enjoy better teaching resources through the Internet.

"Education is an important symbol of a country's development level and development potential." [6] Therefore, in the development of online education, besides the support from school, teachers, parents and students, we also need the government strong backup. Fortunately, the government had realized the deficiencies in the development of online educational, especially in rural areas of western China. Action plan for the education informatization 2.0 was released by Ministry of Education of the People's Republic of China, it requires that "2022, our country should realize the goal of 'Three covers, two improvements and one 
establishment', means that teaching application covers all the teachers, learning applications covers all school-age students, digital campus constructions covers the whole school. The application of information technology and the information literacy of teachers and students will be improved. The large platform of "Internet + Education" will be established." [7]

\section{CONCLUSION}

"Education Informationization has the characteristics of break through the time and space constraints, rapidly replicate and transfer. In order to promote education fairness and improve education quality, we affirm that education informatization is an inevitable choice to adapt to the development of education in an intelligent environment." [7] However, through the practice during the epidemic period, we should realize that there is still a big gap between the development of education informationization in China and the requirements of the new era. In view of the current shortcomings of education informationizationin, we should actively improve the platform construction, constantly improve the information literacy of teachers and students, strengthen the positive online interaction between teachers and students through the platform, and positively promote the cooperation between schools and families. Only by grasping the conditions of the times, making full use of the opportunities and overcoming the challenges, can we open a new chapter of education informationization in our country.

\section{REFERENCES}

[1] Wang.W, (2020, Jan 29). How do student study at home when school is delayed?

Ministry of Education of the People's Republic of China: Use the network platform to achieve the goal of learning continues without face to face classes. Available at http://www.moe.gov.cn/jyb_xwfb/gzdt_gzdt/s5987/2 02001/t20200129_416993.html

[2] Cao P.J. \& Wang S. \&Wang X.N.\& Kang J.C. \& Zhao Z.J. ( 2020, Apr 21 ). Research Group of Chinese Academy of Education Sciences. Six lessons for large scale online education.Guangming Daily.

[3] Zhou H.Y. How does informationization change education in western China - the experience of "classes suspended, but learning continues" Western China Education Development Forum.

[4] Cao P.J. \& Wang S. \&Wang X.N.\& Kang J.C. \& Zhao Z.J. ( 2020, Jun 15 ). Research Group of Chinese Academy of Education Sciences. Under the Epidemic: The Present and Future of Large
Scale Online Education.China Education Daily.[5] Liu Y. Introduction of the situation of online education in primary and secondary schools during the epidemic and the suggestions for the next step by Ministry of Education of the People's Republic of China. Available at http://www.gov.cn/xinwen/2020-05/15/content_551 1824.htm?ivk_sa=1023197a

[6] Ren J.H. \& Gao L. (2018, May 2). General Secretary $X i$ Jinping's suggestions for Education. Available at http://cpc.people.com.cn/n1/2018/0910/c164113-30 282062.html

[7] Ministry of Education of the People's Republic of China. Notice of Ministry of Education of the People's Republic of China on the issuance of the $<$ Action Plan for Educational Informatization 2.0>. Available at

http://www.moe.gov.cn/srcsite/A16/s3342/201804/ t 20180425_334188.html 